\title{
SOB FOGO CRUZADO: A FAMÍlIA DO POLICIAL MILITAR CARIOCA
}

\author{
Fernando Carvalho Derenusson
}

A presente dissertação constitui-se de pesquisa de campo realizada junto a 123 esposas e companheiras de policiais militares da cidade do Rio de Janeiro, com o intuito de avaliar o impacto direto e indireto do trabalho policial sobre a família, sob os eixos de graduação (entre praças) e operacionalidade (policiais do serviço interno e externo). Os resultados indicam que o impacto se faz mais marcante com o passar do tempo de serviço, principalmente em sua forma direta, e sua incidência recai principalmente sobre as famílias vinculadas aos policiais do serviço externo.

\section{BANCA:}

Bernardo Jablonski (Orientador)

Helmuth Ricardo Kruger

Pedro Paulo Gastalho de Bicalho

Data da defesa: 11/03/2009 